\title{
P I 7-23. Enhanced expression of HIV antigens and improved antigen presentation after infection with replication competent attenuated vaccinia virus in vitro
}

\author{
E Quakkelaar*1, A Redeker¹, N Loof ${ }^{1}$, B Perdiguero², P Heinen ${ }^{2}$, J Nieto², \\ M Esteban ${ }^{2}$, K Kibler ${ }^{3}$, B Jacobs ${ }^{3}$, G Pantaleo ${ }^{4}$ and C Melief ${ }^{1}$
}

\author{
Address: ${ }^{1} \mathrm{IHB}$, LUMC, Leiden, Netherlands, ${ }^{2} \mathrm{CNB}$, CSIC, Madrid, Spain, ${ }^{3}$ Arizona State University, Tempe, AZ, USA and ${ }^{4} \mathrm{CHUV}$, Lausanne, \\ Switzerland \\ * Corresponding author
}

from AIDS Vaccine 2009

Paris, France. 19-22 October 2009

Published: 22 October 2009

Retrovirology 2009, 6(Suppl 3):P305 doi:10.1 186/I742-4690-6-S3-P305

This abstract is available from: http://www.retrovirology.com/content/6/S3/P305

(c) 2009 Quakkelaar et al; licensee BioMed Central Ltd.

\section{Background}

Poxvirus vectors, particularly the attenuated and hostrange restricted ALVAC, MVA and NYVAC, have been extensively used to develop the so-called T-cell vaccines. ALVAC has been a major component of a prime/boost vaccine regimen currently tested in phase III clinical trial and MVA and NYVAC have shown good levels of immunogenicity in combination with DNA priming. Despite the promising immunogenicity data, there is common agreement that the poxvirus vector T-cell vaccines need to be improved.

\section{Methods}

In order to improve the immunogenicity of NYVAC we have used two strategies: a) development of attenuated replication competent (in human cells) NYVAC and b) deletion of poxvirus genes known to encode for proteins that may affect the immune response. The newly generated replication competent or gene deletion NYVAC mutants expressing env, gag, pol and nef have been evaluated for their ability to stimulate HIV-specific CD8 T-cell responses from blood mononuclear cells of HIV-infected subjects. HIV-specific immune responses induced by the new NYVAC vectors were evaluated in newly developed direct and cross-presentation assays in vitro and compared with the parental replication deficient NYVAC vector. Finally, expression of gag following infection of different target cells (dendritic cells and HeLa cells) with replica- tion competent and deficient NYVAC vectors was also evaluated.

\section{Results}

The results obtained indicated that replication competent NYVAC vectors induce: a) improvement in direct and cross-presentation, and b) substantial increase in the expression of gag in the infected target cells.

\section{Conclusion}

This project is funded under the CAVD program. 